\title{
Physicochemical Properties, Proximate Composition and Total Viable Counts of Staphylococcus aureus in 'Nono' And Yoghurt Samples in Kaduna, Nigeria
}

\author{
Fausat Adeola Abdulrahman ${ }^{1, a, *}$, Emiade Sanmi ${ }^{2, b}$ \\ ${ }^{1}$ Department of Microbiology, Ahmadu Bello University, Zaria, Nigeria \\ ${ }^{2}$ Department of Microbiology, Federal University of Technology, Minna, Nigeria \\ *Corresponding author \\ A R T I C L E I N F A B S T R A C T \\ Research Article \\ The study aims at determining the physicochemical, proximate composition and the total viable \\ count of Staphylococcus aureus in 'Nono' and yoghurt samples in Kaduna, Nigeria.Three hundred \\ and eighty-four (384) fermented milk samples (Nono and yoghurt) were obtained from different \\ selling points and were evaluated for the occurrence of $S$. aureus. The physicochemical and \\ proximate analyses $(\mathrm{pH}$, total titratable acidity, moisture content, ash content, protein content, and \\ fat content) were determined. The results of the analyses showed that Nono had $\mathrm{pH}$ range of 3.56- \\ 3.61, total titratable acidity: $0.71-1.72$, moisture content: $82.23-83.87 \%$, ash content: $0.30-0.31 \%$, \\ crude protein content: $1.50-1.61 \%$, crude fat content: $0.35-0.38 \%$. For yoghurt, the $\mathrm{pH}$ ranged from \\ $3.76-3.82$, total titratable acidity: $1.10-1.15$, moisture content: $77.76-80.06 \%$, ash content: 0.68 - \\ $0.70 \%$, crude protein content: $3.40-3.45 \%$ and crude fat content: $1.76-1.79 \%$ from all the study \\ areas. One hundred and four of the total samples were contaminated with S. aureus. Out of the 104 \\ isolates of $S$. aureus that were isolated and identified, 88 were coagulase positive S.aureus. The \\ Microgen Staph ID kit (Oxoid) was used to further confirm the characteristics of the 60 isolates of \\ the coagulase positive $S$. aureus. The kit confirmed 43 isolates as $S$. aureus, the results indicated \\ the presence of $S$. aureus in the milk samples which is of public health importance, as this can \\ contribute to food-borne intoxication which can lead to food poisoning. There is a need for proper \\ pasteurisation of raw milk to help eradicate $S$. aureus infection before human consumption. \\ Keywords: \\ Yoghurt \\ Stapylococcus aureus \\ Food poisoning \\ Physicochemical
}

adeolafausat@gmail.com (iD) https://orcid.org/0000-0002-4492-0947

|'@obaemiade@gmail.com

https://orcid.org/0000-0002-8058-2914

(c) (1) (8) This work is licensed under Creative Commons Attribution 4.0 International License

\section{Introduction}

Milk has tremendous nutritional interest to humans and has been consumed since the ancient times and still forms the basis of most nations' economy. It is designed by nature to be complete food for young animals and of high nutritional values. The principal constituents of milk include fat, protein, lactose, ash and in addition to this, it contains several hundred minor constituents which include milk fat, vitamins, metal ion and flavour compounds, which have a major impact on the nutritional and sensory properties of milk and dairy products (Egwaikhide et al., 2014). Milk is a highly valuable food, but raw milk contains and favour the growth of many microorganisms (Helena et al., 2010). Milk and its derivatives are considered as major sources of Staphylococcus aureus infection in man and it may be present in milk and other dairy products (Capuro et al., 2010) which serve as an excellent medium for many kinds of microorganisms. Dairy products constitute an important group of food, known to contain energy and nutrients such as fat, protein, carbohydrates, and calcium. They also make an important contribution to vitamin intake (Igbabul et al., 2013). Yoghurt is a fermented milk product whose characteristic flavour (sour taste) is attributable to the production of lactic acid, acetylaldehyde, acetic acid and diacetyl from carbohydrates by fermenting organisms. It is one of the most popular fermented products widely consumed all over the world and is more nutritious than many other fermented milk products because it contains a high level of milk solids in addition to nutrients developed during fermentation process, and its sensory attributes have a large effect on consumer acceptability (Saint-eve et al., 2008). It is obtained by lactic acid fermentation of milk by the action of a starter culture containing Streptococcus thermophilus and Lactobacillus bulgaricus and it can be in the form of a highly viscous liquid whereas in other countries, it takes the form of a softer gel. Yoghurt is made by the controlled thermoduric fermentation of pasteurized non-fat or low-fat milk, carried out around $45^{\circ} \mathrm{C}$ (Prescott et al., 2008). It is probably the most popular fermented milk product in Nigeria (Nwagu and Amadi, 2010). It is produced both 
commercially and by individuals, using yoghurt- making kits. Commercial starter culture consisting of L. bulgaricus and $S$. thermophilusare used in the fermentation process of yoghurt production (Prescott et al., 2008).

'Nono' is a general name used for locally fermented cow milk and it is widely consumed in many African countries, including Nigeria (Uzeh et al., 2006). Predominantly, Nono is being prepared by the nomadic Fulani cattle herders who control over $80 \%$ of Nigeria's cattle production. It contains amino acid, calcium, phosphorous and vitamin A, B, C and E complex (Nebedum and Obiakor, 2007). Although acclaimed traditionally to have better nutritional values than the unfermented milk, Nono is basically kept unrefrigerated and its acceptability depends on the texture, flavour and taste which are in turn dependent upon the inherent microbial constituents. During milk production, microbial contamination generally occurs from three main sources; from within the udder, from the exterior of the udder and from the surface of milk handling and storage equipment, but the surrounding air, feed, soil, faeces and grass are possible sources of contamination (Solomon et al., 2013). Nono is produced by essentially uneducated Fulani herders in villages with poor knowledge of shelf-life, product safety, sanitation and aseptic milking techniques, handlers of this products may unknowingly introduce pathogenic microorganisms into the products (Godwin and Emmanuel, 2013). These products do not undergo further processing before being sold for consumption and may become potential sources of illness to their consumers (Uzeh et al., 2006). Many dairy products, even those made from pasteurized milk, have been associated with food-borne diseases. This is partly because milk and milk products provide favourable media for microbial growth. Different categories of microorganisms including fungi, bacteria, and viruses could be found in milk since the udder of the animal could harbour organisms while others come as contaminants due to poor handling (Ogbonna, 2011). The aim of this study is to determine the physicochemical, proximate composition and the total viable count of $S$. aureus in Nono and yoghurt samples in Kaduna, Nigeria.

\section{Materials and Methods}

\section{Study Area}

The study was carried out in Kaduna metropolis, Nigeria which comprises 'Kawo' (Kaduna north), 'Bakinruwa' (Kaduna south), and 'Tudun Wada' (Kaduna south). Kaduna state is located at the center of Northern Nigeria with the co-ordinates $10^{\circ} 31^{\prime} \mathrm{N} 7^{\circ} 26^{\prime} \mathrm{E} 10.517^{\circ} \mathrm{N} 7.433^{\circ} \mathrm{E}$. Kaduna is the state capital and the large city. Agriculture and animal rearing namely cattle, sheep, and goat the main occupation of the people of Kaduna.

\section{Collection of Samples}

Three hundred and eighty-four (384) milk samples were collected, of these, one hundred and ninety two (192) samples of locally fermented milk (Nono) were randomly collected into and placed a sterile and chilling container from different selling points in the selected study area and transported without delay to the laboratory for proximate, physicochemical and microbiological analyses while one hundred and ninety-two (192) samples of yoghurt, comprising both sachet and bottled types of yoghurt of different volumes and brands were also obtained randomly from different selling points in the study area as well.

\section{Physicochemical and Proximate Analyses}

The fermented milk samples (Nono and Yoghurt) were analyzed for $\mathrm{pH}$, total titratable acidity, moisture content, total protein, fats and ash. Standard procedure was used according to AOAC, (2005).

\section{pH Determination}

The $\mathrm{pH}$ of the sample was determined using a $\mathrm{pH}$ meter (Cybersan $\mathrm{pH}$ meter, model 500). The electrode of the $\mathrm{pH}$ meter was standardized by dipping it into sterile water after which two different buffers (4 and 7) were used. The set electrode was then used for the various samples by inserting the electrode of the $\mathrm{pH}$ meter in the sample, and readings were recorded.

\section{Total Titratable Acidity Determination}

This was determined by the method described by AOAC (2005). Ten (10) $\mathrm{ml}$ of the samples was dissolved in distilled water and mixed thoroughly. Two (2) drops of phenolphthalein indicator was introduced into $10 \mathrm{ml}$ of the samples (mixed solution). It was titrated against standard sodium hydroxide solution until pink colour persist for 10 seconds for complete neutralization, and the reading was taken and recorded.

$$
\frac{\text { Titre } \times \text { chemical factor of lactic acid }(0.009)}{\text { Volume of sample }} \times \frac{100}{1}
$$

\section{Isolation, Enumeration and Characterization of $S$.} aureus

Serial dilution

Samples of Nono contained in airtight sterile bottle were shaken vigorously to ensure homogeneity. Ten-fold serial dilutions were carried out aseptically according to the Fawole and Oso (2005).

Determination of total viable count in the 'Nono' and yoghurt samples

This was carried out using the nutrient agar by the spread plate techniques from the composite Nono and yoghurt samples. One (1) $\mathrm{ml}$ of the samples was inoculated on the nutrient agar plates and spread over aseptically on the surface of the agar medium using a bent glass rod after flame sterilization. A serial dilution was done for both Nono and yoghurt as described above. The plates were inverted and incubated at $37^{\circ} \mathrm{C}$ for 24 hours. Colonies formed were counted and recorded as total viable count and Colony forming unit/ $\mathrm{ml}(\mathrm{cfu} / \mathrm{ml})$ is calculated as:

$$
\mathrm{CFU} / \mathrm{ml}=\frac{\text { Number of colony counted } \times \text { dilution factor }}{\text { inoculum volume }}
$$

Isolation and identification of Staphylococcus aureus

All the samples were inoculated on mannitol salt agar medium by pipetting one (1) $\mathrm{ml}$ of the samples and spread over aseptically on the agar medium using a bent glass rod after flame sterilization and incubated at $37^{\circ} \mathrm{C}$ for 24 hours. Discrete colonies that were re-inoculated onto Mannitol Salt Agar in order to obtain pure culture of isolates. These pure isolates were then kept at $4^{\circ} \mathrm{C}$ for identification purpose according to the method of Michaylova et al (2007). 


\section{Statistical Analysis}

Data analysis was conducted using IBM SPSS (version 20, Chicago, Illinois, USA) with a one-way analysis of variance (ANOVA). A comparison of means was performed by Duncan's multiple range tests. A value of $\mathrm{P} \leq 0.05$ was considered statistically significant.

\section{Results}

Physicochemical and Proximate analysis of Nono and Yoghurt

The physicochemical and proximate analyses of Nono and yoghurt samples (Tables 1, 2 and 3). The mean value for the pH of Nono ranged from 3.56-3.61, total titratable acidity ranged from $0.71-1.72$, moisture content: 82.23 $83.87 \%$, ash content: $0.30-0.31 \%$, crude protein contents: $1.50-1.61 \%$, crude fat content: $0.35-0.38 \%$, from all the study areas. For yoghurt, $\mathrm{pH}$ ranged from 3.76-3.82, total titratable acidity: 1.10-1.15, moisture contents: 77.76 $80.06 \%$, ash contents: $0.68-0.70 \%$, crude protein contents: $3.45-3.47 \%$ and crude fat contents: $1.76-1.79 \%$.

Total Viable (Colony) Count of the Bacteria in 'Nono' and Yoghurt

The mean values of the total viable count in colony forming unit $/ \mathrm{ml}(\mathrm{cfu} / \mathrm{ml})$ in the Nono and yoghurt samples (Table 4). The results showed that for Nono, the counts obtained from Tudun Wada was high compared to that of Kawo and Bakin-ruwa and there was a significant difference $(\mathrm{P} \leq 0.05)$ in the counts within the study areas. For yoghurt, Tudun Wada recorded the highest bacterial count, followed by Bakin-ruwa and then Kawo.

\section{Identification of $S$. aureus}

Out of the 384 milk samples of Nono and yoghurt tested, $104 \mathrm{~S}$. aureus were isolated. Eighty five percent $(88 / 104)$ of the isolates were coagulase positive while eighty percent $(83 / 104)$ of the isolates demonstrated a Dnase activity (Table 5).

\section{Discussions}

The mean value for $\mathrm{pH}$ of Nono obtained ranged from 3.56-3.61 while that of yoghurt ranged from 3.76-3.82. This is in agreement with the work carried out by Umoh, et al (1991) who reported a $\mathrm{pH}$ range of 3.8-4.4 and 3.7-4.4 for Nono and yoghurt respectively.

Sokolinska et al. (2004) also reported that the $\mathrm{pH}$ value of milk and milk products decreases during manufacturing process from the time it was inoculated with bacteria culture to the time it was manufactured. This is because lactic strains have the ability to ferment lactose into lactic acid thereby increasing the acidity (decrease in $\mathrm{pH}$ ) of the fermented milk products. This is also supported by the findings of Atanda and Ikene (2006) that the fermentation of milk during Nono production reduced the $\mathrm{pH}$ from 6.3to 3.8 due to the production of organic acid.

Table 1. The Physicochemical Composition of the 'Nono' and Yoghurt Samples Used.

\begin{tabular}{l|cccc}
\hline \multirow{2}{*}{ Sample } & \multicolumn{4}{c}{ Physicochemical parameters } \\
\cline { 2 - 5 } \multicolumn{1}{c}{ Location } & \multicolumn{3}{c}{$\mathrm{pH}$} & \multicolumn{2}{c}{ Total titratable Acidity } \\
\cline { 2 - 5 } & 'Nono' & Yoghurt & 'Nono' & Yoghurt \\
\hline Budun Wada & $3.61 \pm 0.15$ & $3.76 \pm 0.06$ & $0.72 \pm 0.10$ & $1.11 \pm 0.02$ \\
Kawin-ruwa & $3.56 \pm 0.16$ & $3.79 \pm 0.03$ & $1.72 \pm 0.04$ & $1.10 \pm 0.08$ \\
Total & $3.57 \pm 0.13$ & $3.82 \pm 0.03$ & $0.71 \pm 0.07$ & $1.15 \pm 0.02$ \\
P-value & $3.58 \pm 0.15$ & $3.79 \pm 0.02$ & $1.05 \pm 0.64$ & $1.12 \pm 0.02$ \\
\hline
\end{tabular}

ANOVA, $\mathrm{P} \leq 0.05, *=$ Significant at $\mathrm{P} \leq 0.05$

Table 2. The Proximate Composition of the 'Nono' Samples Used.

\begin{tabular}{l|cccc}
\hline \multicolumn{1}{c}{ Sample } & \multicolumn{4}{|c}{ Proximate Parameters } \\
\cline { 2 - 5 } \multicolumn{1}{c}{ Location } & Moisture content $(\%)$ & Ash content $(\%)$ & Crude Protein content $(\%)$ & Crude Fat content $(\%)$ \\
\hline Tudun Wada & $82.23 \pm 0.40^{\mathrm{b}}$ & $0.30 \pm 0.04^{\mathrm{a}}$ & $1.50 \pm 0.03^{\mathrm{b}}$ & $0.35 \pm 0.02^{\mathrm{a}}$ \\
Bakin-ruwa & $82.78 \pm 0.51^{\mathrm{b}}$ & $0.31 \pm 0.04^{\mathrm{a}}$ & $1.61 \pm 0.02^{\mathrm{a}}$ & $0.35 \pm 0.02^{\mathrm{a}}$ \\
Kawo & $83.87 \pm 0.50^{\mathrm{a}}$ & $0.30 \pm 0.04^{\mathrm{a}}$ & $1.57 \pm 0.03^{\mathrm{ab}}$ & $0.38 \pm 0.01^{\mathrm{a}}$ \\
Total & $82.95 \pm 0.28$ & $0.31 \pm 0.01$ & $1.56 \pm 0.02$ & $0.36 \pm 0.01$ \\
P-value & $0.047^{*}$ & 0.204 & $0.013^{*}$ & 0.438 \\
\hline
\end{tabular}

ANOVA, ${ }^{*}=$ Significant exist at $\mathrm{P} \leq 0.05,(\%)=$ Percentage

Table 3. The Proximate Composition of the Yoghurt Samples Used.

\begin{tabular}{l|cccc}
\hline Sample & Proximate Parameters & & & \\
\cline { 2 - 5 } Location & Moisture content $(\%)$ & Ash content $(\%)$ & Crude Protein content $(\%)$ & Crude Fat content $(\%)$ \\
\hline Tudun Wada & $77.76 \pm 0.66$ & $0.68 \pm 0.05$ & $3.47 \pm 0.01$ & $1.79 \pm 0.02$ \\
Bakin-ruwa & $78.68 \pm 0.75$ & $0.70 \pm 0.01$ & $3.45 \pm 0.01$ & $1.79 \pm 0.03$ \\
Kawo & $80.06 \pm 0.39$ & $0.69 \pm 0.04$ & $3.45 \pm 0.01$ & $1.76 \pm 0.02$ \\
Total & $78.83 \pm 0.36$ & $0.69 \pm 0.01$ & $3.46 \pm 0.01$ & $1.78 \pm 0.01$ \\
P-value & $0.032 *$ & 0.091 & 0.226 & 0.723 \\
\hline
\end{tabular}

ANOVA, $\mathrm{P} \leq 0.05, *=$ Significant at $\mathrm{P} \leq 0.05,(\%)=$ Percentage 
Table 4. Mean value for the Total Viable Counts in 'Nono' and Yoghurt (cfu/mL).

\begin{tabular}{l|cc}
\hline \multicolumn{1}{c|}{ Sample location } & 'Nono' & Yoghurt \\
\hline Tudun Wada & $1.29 \times 10^{5} \pm 1.56 \times 10^{5 \mathrm{a}}$ & $3.91 \times 10^{3} \pm 7.76 \times 10^{5 \mathrm{~b}}$ \\
Bakin-ruwa & $7.63 \times 10^{4} \pm 3.60 \times 10^{5 \mathrm{~b}}$ & $1.87 \times 10^{3} \pm 1.93 \times 10^{3 \mathrm{a}}$ \\
Kawo & $1.19 \times 10^{5} \pm 9.88 \times 10^{5 \mathrm{~b}}$ & $1.78 \times 10^{3} \pm 1.99 \times 10^{3 \mathrm{a}}$ \\
P-value & $0.017^{*}$ & $0.018^{*}$ \\
\hline
\end{tabular}

ANOVA, \pm SEM=Standard error mean, cfu/ml= Colony forming unit per $\mathrm{ml}$

Table 5. Biochemical Characteristics of S. aureus isolates of 'Nono' and Yoghurt Samples tested

\begin{tabular}{ll|ccc}
\hline \multirow{2}{*}{ Test } & \multicolumn{3}{c}{ Numbers of Positive (\%) } \\
\cline { 3 - 5 } & Catalase & 'Nono' & Yoghurt & Both \\
\hline 1. & Coagulase & $64(100)$ & $20(100)$ & $104(100)$ \\
2. & DNase & $63(80)$ & $20(100)$ & $88(85)$ \\
3. & D & $20(100)$ & $83(80)$ \\
\hline
\end{tabular}

The $\mathrm{pH}$ of Nono recorded in this study is in contrast with the pH 5.7 recorded by Obi and Ikenebomeh, (2007), 5.51-6.29 reported by Adesokan et al. (2011); $\mathrm{pH} 4.09-4.42$ by Egwaikhide et al. (2014) and 3.7-6.5 reported by Okeke et al. (2014) while for yoghurt the $\mathrm{pH}$ is in contrast with the $\mathrm{pH}$ of 3.8-5.4 reported by El-Bakri and El-Zubair (2009); pH of 4.73-5.11 by Igbabul et al. (2013) and pH of 5.35 by Omola et al. (2014). The difference in their $\mathrm{pH}$ could be as a result of some factors like length of fermentation and the starter culture used. The effect of length of fermentation of milk samples could results to increase in acidity of the milk samples, thereby leading to the reduction of $\mathrm{pH}$ which determines the number and kinds of contaminating micro organisms present in the milk sample. The Total titratable acidity (TTA) of Nono, shows that the mean value ranged from 0.71-1.72, and that of yoghurt ranges from 1.10-1.15.The TTA obtained from the milk products might be due to the facts that titratable acidity of the raw milk increases on storage due to the action of microorganism and as fermentation progresses or continues titratable acidity of the milk products increases. Increase in TTA (That is, reduction in $\mathrm{pH}$ ) could be attributed to accumulation of some organic acid and acetic acid which could results from the activities of some fermentative microorganisms such as Lactic acid bacteria and yeast in the milk samples. These mean values of the total titratable acidity of Nono obtained in this work are higher compared to the mean value of 0.6-0.9 reported by Umoh et al. (1991). However, the mean value of the total titratable acidity of yogurt is in agreement with the findings of Umoh, et al (1991) who reported a TTA of 0.9-1.4, but in contrast with the report of Okeke et al.(2014) who recorded a TTA range of 0.1-0.9, Egwaikhide and Faremi, (2010) recorded a lower TTA range of $0.14-0.16$ and Igbabul et al.(2013) who reported TTA of 0.90 0.93. However,there was no significant difference in the total titratable acidity of both samples.

There was a significant difference in the moisture content of both samples $(\mathrm{P} \geq 0.05)$. This is in agreement with the work of Igbabul et al. (2013) who stated that the maximum moisture content in yoghurt to be $84 \%$. When there is an increase in moisture content of milk it implies increase in water activity $\left(a_{w}\right)$ which can support microbial growth and consequently reduces the shelf life of the milk products (Ajai et al.,2012). The mean value for the ash content of Nono was $0.30-0.31 \%$ while that of yoghurt is $0.68-0.70 \%$. The value recorded in these findings might be due to the facts that ash content is an index of mineral content. This is in agreement with the work reported by Umoh et al. (1991) who reported ash content of 0.24-0.37\% and $0.75 \%$ in Nono and yoghurt respectively, Ladokun and Oni, (2014), who reported $0.52-0.96 \%$ in yoghurt and that of Igbabul et al. (2013) who reported ash content of 0.41$1.02 \%$. But in contrast with the ash content of $0.2-1.80$ by Egwaikhide et al. (2014). The higher ash content recorded in their findings might arise from increase in water content, increase percentage of fermentable bacteria and higher mineral content. The ash content value is said to be an index of mineral content which is needed for bone development, teeth formation and body function of the consumer (Trachoo and Misty, 1998).The Crude protein content for Nono ranged from 1.50-1.61\% while that of yoghurt was $3.45-3.47 \%$. This is in agreement with the work of Umoh et al. (1991) who reported protein content of $1.21-1.90 \%$ in Nono and $3.45 \%$ in yoghurt but disagrees with the protein content of $2.73 \%$ in Nono reported by Egwaikhide et al. (2014). The low protein content observed in Nono from this study might be attributed to the practice of dilution of milk with water after fermentation by the handlers of Nono to increase the volume. For yoghurt, the crude protein value obtained was lower than 4.02-6.14\% that was reported by Igbabul et al. (2013) and 3.5\% reported by Eearly (1988). The increase in crude protein content of yoghurt could be due to some anabolic processes leading to polymer build up or due to microbial cell proliferation. There was a significant difference in the protein content of the Nono samples $(\mathrm{p} \geq 0.05)$. The mean value for the crude fat content of Nono ranged from 0.35 $0.38 \%$ while that of yoghurt was $1.76-1.79 \%$. This is in agreement with the work reported by Umoh et al. (1991) who reported fat content of $0.08-0.68 \%$ in Nono and Igbabul et al.(2013) who reported $1.32-3.25 \%$ in yoghurt samples and is in contrast with the work carried out by Umoh et al. (1991) who reported fat content of $2 \%$, (Ladokun and Oni, 2014) that reported a high fat content of 9.76-15.02\% from different milk types and Omola et al.(2014) who reported fat content of $1.5-2.5 \%$. The decrease in crude fat content observed in the milk samples could be as a result of increase in fermentation time which might be attributed to increased activities of lipolytic enzymes during fermentation which also hydrolyzes fat components (Triacylglycerol) into fatty acid and glycerol. Fat content are usually higher in food of animal origin than plant origin as fat content of food is the major contributor 
to energy value of food. As reported by Astuti et al., (2000) that the fatty acid were used by some microorganisms such as moulds resulting in decrease in fermentation in the fermenting milk samples at the end of fermentation. Although, the total viable counts in yoghurt (1.78-3.91) $\mathrm{x} 10^{3} \mathrm{cfu} / \mathrm{ml}$ is within the acceptable limit of $10^{3}-10^{4} \mathrm{cfu} / \mathrm{ml}$ in accordance to the guidelines for the microbiological quality of food samples (Gilbert et al., 2000). Also, $<$ $10^{5} \mathrm{cfu} / \mathrm{ml}$ of total viable counts(TVC) of yoghurt was regarded as the marginal limit of acceptable microbiological quality of food based on standard methods of International Commission on Microbiology Speification of Food (ICMSF, 1996). A TVC of $>10^{6} \mathrm{cfu} / \mathrm{ml}$ is regarded as potentiall haardous. Though, the TVC obtained for yoghurt in this study is lower than that of Nono but it might be an indication of contamination of the yoghurt samples either during packaging or at the preparatory stage or during handling or poor handling of yoghurt during processing and packaging of the products. Nono being the local version of yoghurt recorded a higher count (7.631.29) $\times 10^{5} \mathrm{cfu} / \mathrm{ml}$ than yoghurt and there is a significant difference in these counts. The higher counts in Nono might be due to handling of the products, processing or sanitary condition of the handlers, low level of hygiene maintained during processing and sale of the product (Nono), quality of water used (for both Nono and yoghurt), the utensils, exposure of Nono while it is usually displayed for sale in the bowl as all these can serve as sources of contamination to the product. Also, the higher counts observed in Nono might be due to the facts that its keeping time is longer before consumption and this increases the acidity (as observed in this study, Nono has a low $\mathrm{pH}$ ). This means an increase in acidity determines the numbers of contaminating organisms. Other reasons for higher counts observed in Nono could be as a result of the length of time of storage of raw milk used for the production of Nono which might allow for microbial contaminants to multiply and increase in number thereby influencing the total viable/bacteria counts and the types of bacteria present in the bulk raw milk. Most handlers or sellers of Nono are street peddlers and often not all Nono that are brought to the market by the peddlers are sold the same day, such unsold ones are reintroduced into the market with no further treatment or proper preservation. Thus, allowing pathogenic organisms to gain access into the products and have enough time to multiply and produced harmful metabolites.

The street peddlers usually add left over Nono of the previous day or previously fermented Nono (back slopping) as a starter culture for the production of Nono, by so doing the organisms (particularly $S$. aureus) have enough time to multiply thereby increasing the bacteria counts in the Nono. In this Study, $80 \%$ of the staphylococci isolates were Dnase positive which is much higher than the study demonstrated by Sulaiman, (2011) which recorded $78 \%$ of the isolates to be Dnase positive. Although the high specificity and sensitivity of the coagulase test (Blobe and Schlisser, 1994) has made it to be considered a standard method for the identification of S.aureus but in this study $85 \%$ of the $S$. aureus were positive in the slide coagulase test which is not in agreement with the study carried out by Sulaiman, (2011) that reported a $100 \%$ of $S$. aureus being positive in the coagulase test after 4 hours of incubation.
This probably implies that the isolates from that study is of human origin. The difference might also be due to the method used or the fact that the milk samples in this study have undergone some processing. The microgen Staph ID kit proved successful in identifying 43 isolates out of 60 (72 of the $S$. aureus on which it was applied. The remaining 17 isolates were identified as S.xylosus, S.intermedius, S. chromogenes, S. hyicus, S. cohnii and S.heamolyticus respectively. This discrepancy in the use of biochemical test kit and the conventional biochemical tests can be explained by the facts that conventional methods failed to distinguish between $S$. aureus, S.intermedius and $S$. pseudintermedius (Sasaki et al., 2007).

\section{Conclusion}

The Microgen Staph ID kit was demonstrated to be more efficient for the detection and identification of S.aureus from the milk samples, user-friendly and seems to be better at differentiation at species level. The presence of $S$. aureus in the milk samples is of public health importance, as this can contribute to food-borne intoxication which can lead to food poisoning. There is need for proper pasteurization of raw milk and fermentation of milk to help eradicate $S$. aureus infection before human consumption.

\section{References}

Adesokan IA, Odetoyinbo BB, Ekanila YA, Avanrenren RE, Fakorede O. 2011. Production of Nigerian Nono using Lactic starter culture. Park Journal of Nutrition, 10: 203-207.

Ajai AI, Ochigbo SS, Ndamitso MM, Ola OJ. 2012. Proximate and Mineral Composition of different raw cow milk in Minna,Niger State, Nigeria. European Journal of Applied Engineering and Scientific Research, 1: 23-29.

AOAC. 2005. Official method of Analysis'Association of Official and Analytical Chemist, Washington DC $\left(12^{\text {th }}\right.$ ed $)$.

Astuti M, Andreanyta M, Fabien SD, Mark L. 2000. Tempe, a nutritious and healthy food from Indonesia. Asia pacific Journal of Clinical Nutrition, 1(4), pp 322-325.

Atanda OO, Ikenebomeh MJ. 2006. Microbiology quality of nono. World journal of Microbiology, 1(17): 89-91.

Blobe H, Schliesser T. 1994. Handbuch der bakteriellen Infektionenbei Tieren.Staphylokokken-Infecktionen und Enterotoxine, 2, part 1. Gustav Ischer verlag Jena Stuttgart, Germany. Pp 680-683.

Capuro A, Aspan A, Unnerstad HE, Walker KP, Artursson K. 2010. Identification of potential sources of Staphylococcus aureus herds with mastitis problems. Journal of Dairy Science. 93: 180-191.

Eearly R. 1998. The technology of dairy products $\left(2^{\text {nd }} e d\right)$. International Thompson Publishers. Pp 124-146.

Egwaikhide PA, Faremi AY. 2010. Bacteriological analysis of locally manufactured yoghurt, Electronic Journal of Environmental Agriculture and food chemistry 9 (11): 16791688.

Egwaikhide PA, Malu PS, Lawal U, Adelagun RO, Andrew C. 2014. Physicochemical and Microbiological analysis of Fermented cow milk (Nono) consumed within Kaduna town, North western, Nigeria. 29: 2225-2557.

El-Bakri JM, El- Zubeir JEM. 2009. Chemical and Microbiological evaluation of plain and fruit yoghurt in Khartoum State, Sudan. International Journal of Dairy Science.4: 1-7.

Fawole M, Osho BA. 2005. Laboratory manual of Microbiology. Revised edition, Spectrum books Ltd, Ibadan, pp 127. 
Gilbert GJ, de louvas T, Donovan C, Littles K, Nye CD, Riberio J, Richards D, Roberts F, Bolton J. 2000. Guidelines for themicrobiological quality of some ready-to-eat food samples at the point of sale. Communicable Disease and Public Health, 3: 163-167.

Godwin AO, Emmanuel TA. 2013. Extent of microbial contamination of nono, fresh cow milk and yoghurt sold in Makurdi, Benue State, Nigeria. Journal of Microbiology andBiotechnology Resources, 3 (3):6-14.

Gundogan N, Avc1 E. 2014. Occurrence and antibiotics resistance of Escherichia coli,Staphylococcus aureus and Bacillus cereus in raw milk and dairy products in Turkey. International Journal of Dairy Technology, DOI:10:1111/14710307,12149 .

Helena F, Luciana B, Antonio NF, Luciano MF, Carlos A, Fernandes O. 2010. Occurrence of Staphylococcus aureus in raw milk produced in dairy farms in Sao Paulo State, Brazil. Brazillian Journal of Microbiology. 41: 1517-1532.

ICMSF. 1996. International Commission on Microbiology Specification of Food, Microorganism in foods 5. Blackie Academic Professional, New York.

Igbabul B, Shember J, Amore J. 2013. Physicochemical, Microbiological and Sensory evaluation of Yoghurt sold in Markudi metropolis, Benue State, Nigeria.

Ladokun O, Oni S. 2014. Fermented milk products from different milk types. Journal of food and nutrition science.vol 5:13.

Michaylova M, Minkova S, Kimura K, Sasaki T, Saira K. 2007. Isolation and characteristics of Lactobacillus delbruckii spp bulgaricus and Streptococcus thermophillus in Bulgaria, Microbiology Letter 269: 160-169.FEMS

Nebedum JO, Obiakor T. 2007. The effects of different preservation methods on the quality of nono: A locally fermented Nigerian Dairy products. African Journal of Biotechnology, 6: 454-458.

Nwagu TN, Amadi EC. 2010. African Journal of Microbiology Research, 4(10): 984-988.

Obi CN, Ikenebomeh MJ. 2007. Studies on the microbiological, nutritional quality of a Nigerian fermented milk products (nono). International Journal of Dairy Science, 2: 95-99.

Ogbonna IO. 2011. Microbiological Analysis and Safety Evaluation of Nono: A Fermented milk product consumed in most part of Northern Nigeria. International Journal of Dairy Science, 6, 181-189.
Okeke SK, Abdullahi IO, Makun HA. 2014. Microbiological quality of dairy cattle products. British Microbiological Research Journal. 4(12): 1409-1417.

Omola EM, Kawa AH, Shamsuddeen U. 2014. Physicochemical, Sensory and Microbiological Qualities of Yoghurt brands sold in Kano, Kano state, Nigeria. Bayero Journal of pure and applied sciences, 7(2): 26-30.

Prescott ML, Harley PJ, Donald AK. 2008. Microbiology ( $7^{\text {th }}$ ed.). New York: McGraw Hill, 1038-1049.

Saint Eve A, Leng C, Morgnehe M, Durvet SI. 2008. Quality changes in yoghurt during storage in different packaging materials. Food Chemistry, 110:285-293.

Sasaki T, Kikuchi K, Tanaka Y, Takahashi N, Kamata S, Hiramatsu K. 2007. Methicillin-resistant Staphylococcus pseudintermedius in a veterinary teaching hospital. Journal of Clinical Microbiology, 45: 1118-1125.

Sokolinska DC, Michalski MM, Pikul 2004. Role of the proportion of yoghurt bacterial strains in milk souring and the formation of curd qualitative characteristics. Bulletin of the Veterinary Institute in Pulawy, 48: 437-441.

Solomon M, Mulisa M, Yibeltal M, Desalegn G, Simenew K. 2013. Bacteriological quality of bovine raw milk at selected dairy farms in Debrezeit town, Ethiopia. 1(1): pp. 1-8.

Sulaiman AB. 2011. Phenotypic and Genotypic characterization of Staphylococcus aureus isolated from mastitic milk in Northern part of Plateau State, Nigeria. PhD dissertation, Vet. Public Health \& Preventive medicine, A.B. U., Zaria.

Trachoo N, Misty VV. 1998. Application of ultra-filtered sweet butter milk and sweet butter milk powder in the manufacture of non-fat and low fat yoghurt. Journal of Dairy Science, 81: 774-778.

Umoh VJ, Adesiyun AA, Gomwalk NE. 1991a Proximate and sensory analyses of 'nono', commercial and laboratory prepared yoghurt and some milk and milk products. Tropical Journal of Applied Science.1: 128-134.

Uzeh ER, Ohenhen ER, Rojugbokan KA. 2006. Microbiological and Nutritional Qualities of Dairy Products: Nono and Wara. Journal of Nature and Science. 4(3): 37-40. 